\title{
Educating the Silenced: Threads of Visual Culture in Domesticating the Wives in Malaysia
}

\author{
Noraini Md. Yusof ${ }^{1} \&$ Esmaeil Zeiny ${ }^{1}$ \\ ${ }^{1}$ Institute of Malaysian and International Studies (IKMAS), National University of Malaysia (UKM), Malaysia \\ Correspondence: Esmaeil Zeiny, Institute of Malaysian and International Studies (IKMAS), National University \\ of Malaysia (UKM), 43600 Bangi, Selangor, Malaysia. Tel: 60-178-799-036. E-mail: mehdizeiny@gmail.com
}

Received: February 19, 2015 Accepted: March 29, 2015 Online Published: July 27, 2015

doi:10.5539/ies.v8n8p41

URL: http://dx.doi.org/10.5539/ies.v8n8p41

\begin{abstract}
As a very controversial issue in Islam, polygamy allows Muslim men to marry up to four wives. It has been told that the Quran encourages polygamy; thus, it is a part of Islamic Sharia. Many Muslim men practice it at their whim and they contend that they do so to follow the Sunnah. Amongst Muslim countries, Malaysia is one of those countries where polygamy is rife. To make it as an acceptable Islamic practice and a more common phenomenon, polygamy is favoritized and advocated through the mass media such as TV shows and newspapers. Although suffering agonizing experiences of being a co-wife, many Malay Muslim women cannot resist polygamy as they think it would be a rebuttal of religion. As a counter-argument of the seemingly happy images of polygamous marriages in Malaysia, this paper exhibits the vicissitudes of it through analyzing a documentary entitled 'Four Wives - One Man' and it demonstrates that the traditional interpretation of the Quran as regards to polygamy is in favor of patriarchy and cannot be appropriate. Utilizing the Contextualist interpretation of the Quran, this paper tries to educate the silenced women that polygamy is, indeed, not encouraged and questioning it would not mean disobeying the Quran.
\end{abstract}

Keywords: polygamy, polygyny, women, Islam

\section{Introduction}

The issue of women's right has been the most controversial issue in all societies. Throughout the centuries, it has been assumed that there is a huge discrepancy between male and female not only in basic anatomy but also in terms of thinking and acting. What causes this assumption can be traced back to the creation of Adam and Eve where Eve is created from Adam's rib to be his mate. Having eaten the forbidden fruit, Eve was castigated with laborious childbirth as a punishment of her misdemeanor. This primordial story of human creation had a dramatic impact upon the orientation of women's body as an inferior and subordinate figure. The male domination and discrimination against women put them in an inferior position to that of men; the Christian church of the time reinforced this attitude by practicing the discrimination against woman. Many women were not even aware of their rights even in the West until the commencement of the nineteenth century AD when they started to fight for their rights which led to suffragette movement at the outset of the twentieth century. Consequently, women formed different liberation movements in various parts of Europe and America and gained their social, economic, and political rights denied to them earlier. It is worthwhile to mention that the reinterpretation of the Christian text and its values played a significant role in discarding the male biasness against women (Syed, 2004).

Eastern Women's position before the emergence of Islam was even worse than that of women in the west. The patriarchal domination of those societies has turned women into a commodity. They were treated as a mere property that could be exchanged at times and inherited by the husband's heirs. The revelation of the Holy Quran and the Hadith of the Prophet Mohammad (pbuh) changed the sentiment towards women. The Islamic reforms through the Holy Quran assisted women to gain almost equal rights to those of men. However, as Syed (2004, p. 2) asserts, the "male-dominated Arab society resisted the ideals of sexual equality prescribed by the Quran and the Hadith."The male domination of the pre-Islamic Arab society was preserved by the then conservatives and traditionalists. These conservative men held the status quo of the women as inferior and tried hard to justify their act through the bias interpretation of the Holy Quran. Many rights that have been conferred on women by the Holy Quran 1400 years back are denied by the male (mis)interpretation of the Holy book. The 
(mis)interpretations by these conservative framers of Sharia deprived Muslim women of their so many rights; these male interpreters, instead, conferred various rights to men ideologically which are being practiced even today. One such right is the right of a Muslim man to marry four wives. Hence, Muslims believe that polygamy is allowed in Islam. Muslim women do not object to their husband's polygamous marriage as they have been (mis)educated that Islam allows it; therefore, they cannot have anything against it. Although sharing their husband with someone else makes them suffer emotionally, they keep quiet to this violence of domesticating the harem. This conjures up Napoleon Bonaparte's famous statement on religion: "religion is excellent stuff for keeping common people quiet" (n.d.)

As a religious practice, polygamy is practiced rampantly in Malaysia. As visual culture is "the images and objects we encounter in our daily lives" (Heise, 2004, p. 41), new media technologies such as TV shows, internet and newspapers are the means of popularizing polygamy in Malaysia. It is high time that the patriarchal rulers of the society found out that visual culture shapes people's lives and construct their sense of culture and identity. They are aware of the fact that "the world-as-a-text has been replaced by the world-as-a-picture" (Mirzoeff, 1999, p. 7). Using visual culture, they can transmit their desired codes and values of polygamy to the grassroots. Understood in this fashion, images of apparent happy polygamous families are being produced and reproduced in galore to corroborate the (mis)education that polygamy is a holy practice. Concomitant with these images are the posters and flyers which support polygamy and represent it as a positive practice and a blessing (Figure 1). These images are thrusting polygamy into popular culture in Malaysia so much so that the number of second and third wives is increasingly growing. W.J.T Mitchell's 'picture theory' (1994) or 'visual culture' in a broader term has made a significant contribution to the patriarchal system of the society in normalizing polygamy in Malaysia. Portrayals of seemingly happy co-wives along with their husband are used to show that polygamy is a great way to combat social ills such as prostitution and conjugal betrayal. 

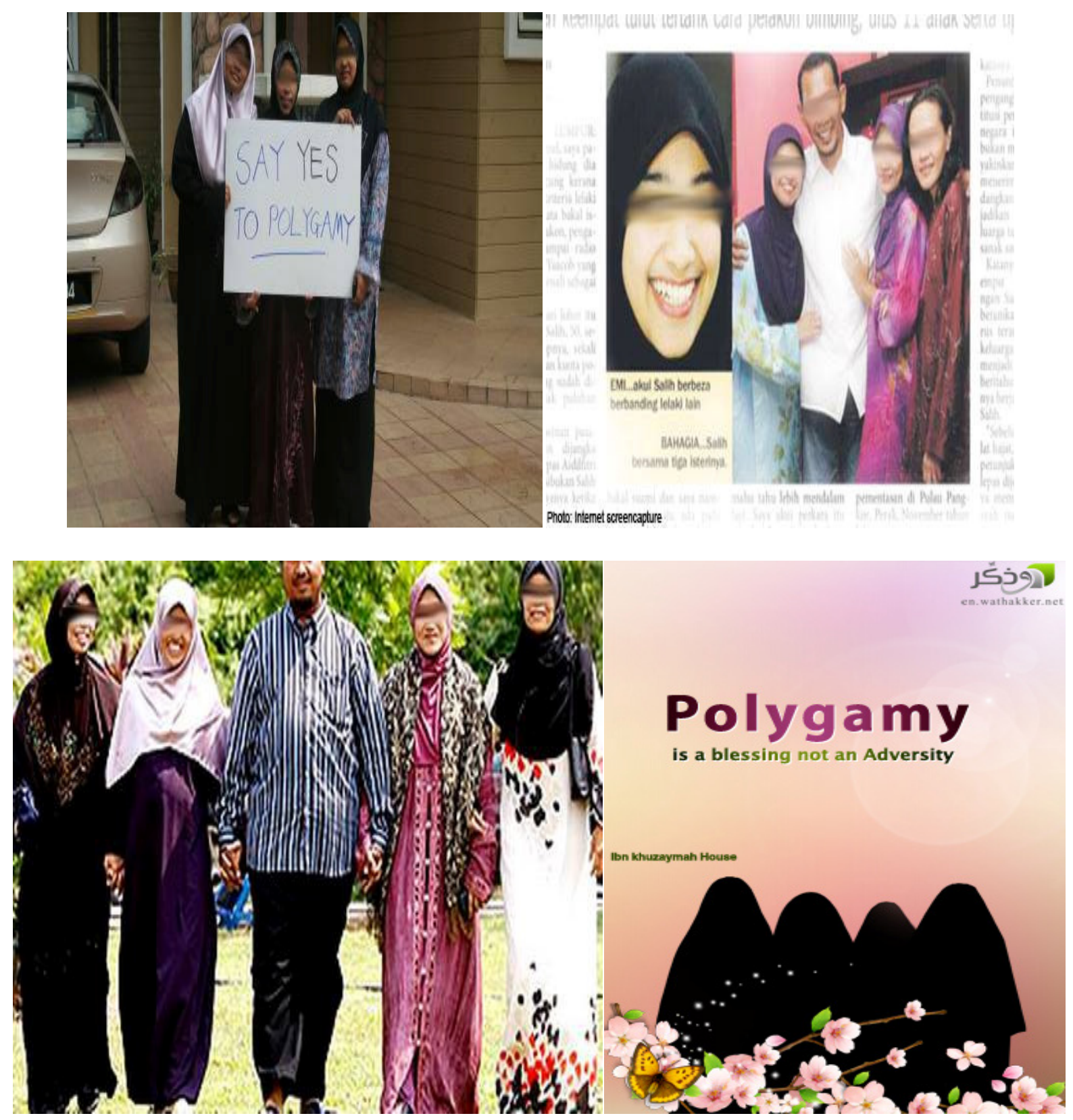

Figure 1. Images of polygamous families and a flyer on polygamy

A great number of these images have been going viral through TV shows and video clips. 'Polygamy in Harmony in Malaysia' is a short film on one husband and four wives. The film shows no trace of suppression and jealousy amongst women. They seem to have a happy and peaceful life. The co-wives are seen as never fight with one another though they admit that they have their own misunderstanding. However, they say "we forgive and forget." The man of the family is proud of his polygamous marriage and he boasts of being a good leader which shows his patriarchal ideology. Another short film on polygamy in Malaysia exhibits a man and his four wives living with their twenty three children. They are all shown as one big happy family living a rosy life. "Joining the obedient wives club" is another of these films on polygamy where the new bride believes that she cannot and should not say anything against her husband's second marriage as it is the word of God. She opines that a wife should be obedient and always at her husband's beck and call. Patriarchy is so rooted in the psyche of Malays to the extent that even many Malay women believe polygamy should be practiced as it promotes positive social morals. Utilizing visual culture to promote patriarchy and polygamy has been a successful strategy up until now but statistics shows that polygamy leaves a trail of devastation in the form of ignored wives and 
dysfunctional children (Mokhtar, 2010). Many children of polygamous marriages realize that this practice harms their families. In a survey conducted by Sisters in Islam (SIS) on Malay children in 2010, 90 percent of the 523 children insisted that they would never engage in polygamy when they grew up (Lane, 2010). Mokhtar (2010) argues that what makes polygamy a more common phenomenon is the federal Islamic Family Law. In 1984, Malays were required to fulfill five conditions before having a polygamous marriage: financial stability, fair treatment, no harm to the existing wife or wives, the new marriage was 'just and necessary' and the proposed marriage should not lower the existing wives and children standard of living. However, in 1996, the law has erased the final term and in 2004, the 'just and necessary' was modified to 'just or necessary'.

\section{Polygamy in Quran and its Interpretations}

Polygamy is derived from the Greek terms of 'poly' and 'gamy.' 'Poly' means 'many' and 'gamy' means 'marriage.' It refers to marriages in which spouses of either sex have more than one mate simultaneously. The word 'polygamy' contains two terms of polygyny (marriage between a man and two or more women) and polyandry (a marriage between a woman and two or more men) (Jones, 1994, p. 268; Bretschneider, 1995, p. 50). Hereafter, the term 'polygyny' will be used to refer to a marriage between a man and two or more women. Polyandry is not allowed in Islamic Sharia but polygyny is being practiced in Muslim communities worldwide. Under the Islamic Sharia, a husband enjoys many benefits but his wife does not. For example, a Muslim woman is not encouraged to marry a non-Muslim but a Muslim man may do so; the Islamic Sharia does not specify any punishment for a husband who rapes his wife; while a wife has to face the fate of sharing her husband with up to four wives, polyandry is strictly proscribed. Islamic Sharia allows polygyny based on the Quranic verse of “... marry women of your choice, two or three or four; but if you fear that you shall not be able to deal justly with them, then only one" (Quran 4:3). Those Muslim men engaged in polygamous marriages use this verse of the Holy Quran to legitimize their practice of polygyny.

Although currently not common in all Muslim societies, unfortunately, polygyny is on an increasing trend amongst Muslim communities under the influence of Ulama. Saeed (2006) categorizes two types of Muslims who believe in polygyny: Textualist and Semi-Textualist. This classification is based on the "degree of the interpreters' (1) reliance on linguistic criteria to understand the meaning of the text; (2) consideration of the socio-historical context of the Qur'an and the current context" (Saeed, 2006 quoted in Nurmila, 2009, p. 42). The first group, the Textualist, believe that Islam permits polygyny based on their literal reading of some parts of the verse 4: 3 where it says marry women of your choice, two, or three, or four; and advocate their idea by referring to the Prophet Muhammd's practice of polygyny (following the Sunnah) and other justifications on different grounds that have never been mentioned in the Quran. When asked by a Hindu girl that why a Muslim man can marry up to four wives and why not one husband and one wife, Zakir Naik comes up with the simplistic idea that women outnumber men in most parts of the world. While emphasizing that it is not compulsory, he believes that women are better to be taken as co-wives instead of living a life of infamy and becoming a public property (prostitute); hence, polygyny ensures a decent and dignified life for women (http://www.youtube.com/watch? $\mathrm{v}=8 \mathrm{Sdzfwen}-\mathrm{yo}$ ). Therefore, the current myth promoting polygamy is a surfeit of women which is nowhere near the fact.

The questions to be raised here are (a) why do unmarried women become public property? (b) doesn't this attitude reinforce the idea of women as a commodity? Other arguments in favor of polygyny are about men's sexuality; they argue that men's sexual needs are greater than those of women and men have to marry another wife because he needs to have sexual intercourse when his wife is going through periods or when she is pregnant Another argument revolves around a barren woman; they are of the idea that it is always better to marry a second wife in times of infertility of the first wife rather than divorcing her which makes her psychologically wreck (Ali, 2002). All these justifications are suggestive of the strong patriarchal hold in Muslim societies. However, these justifications can be refuted based on the arguments that it is not proven either biologically or scientifically that a woman's sexual needs are any less than that of a man. A man is not like an animal that cannot control his sexual drive; he can restrain his sexual drive just like so many other men who are not engaged in polygamous marriages. The institution of marriage means more than sexual gratification. Marriage is not an institution of prostitution where the male want to fulfill his sexual lust and keep woman under his authority. On women's infertility, one can argue that men can also be barren and modern scientific advances make other feasibilities for a barren woman.

Influenced under the above-mentioned justifications of proponents of polygyny, sadly, a great number of Muslim women accommodate their husband's polygyny to show their devotion to Islam unaware of the fact that there is no specific verse in the Holy Quran that allows polygyny rather it is the interpretation of the Quran that allows it so (Nurmila, 2009). Most of them have been inculcated that their husband should follow the Sunnah as Prophet 
Mohammad (pbuh) practiced polygyny. These women believe that it is better for a man to marry a second wife instead of committing adultery as a man cannot control his sexual drive. They argue that they should allow their husband to marry another wife otherwise they are responsible for their husband's adultery. To them, polygyny seems like a trial by God, so they cannot discord to their husband's polygyny. To show that they are a good pious wife, at times they help their husband in finding a woman to marry. Almost all of these women suffer psychologically and emotionally deep down in their heart but remain taciturn as they reckon polygyny is God's law and religiously accepted. On her husband's second marriage, Tuti, a women from Indonesia, assert:

On the day of my husband's marriage, I prepared and ironed his clothes. I helped him get dressed. It was also I who provided money to pay for Nuri'smahar because my income was higher than that of my husband. My husband kissed my feet to ask for my forgiveness before he went out for his second marriage. I could not stand to attend the wedding. I stayed at home with my children who asked where their father was when he did not come home that night. I said to them that their father was attending a meeting. I could not sleep that night. I felt that my heart was very hot. To cool down my feelings, I spent that night praying and reading the Qur'an (Quoted in Nurmilla, 2009, p. 95).

There are Muslims who opine that polygyny is only allowed when men are able to be just to their wives; they belong to the second group of the categorization, Semi-Textualist. Irrespective of the context of the verse revelation regarding orphans, the idea of this group is based on a literal comprehension of verse 4:3where it mentions: marry women of your choice, two, or three, or four; but if ye fear that ye shall not be able to deal justly, then only one, or that which your right hand possess. That will be more suitable, to prevent you from doing injustice... This group believe that Islam has restricted men to marry up to four wives whereas there was no limitation on the number of wives in pre-Islamic period (Nurmila, 2009). It is almost next to impossible for a polygynous husband to be fair and just to each of his wife. He cannot invest equal time, emotion and maintenance with his wives. In the past, men might have been just in a polygynous marriages but nowadays polygyny has been converted into a corrupt practice of unbridled lust. Some Muslims argue that polygyny is conducive to the welfare of women or a society but it cannot be constructive as it is devoid of justice and equity; many women suffer from agonizing experiences of their husband polygynous marriages. As a woman who suffered from the upshot of polygyny, Lina asserts:

I believe that my current sickness is caused by my husband's polygamous marriage. I believe that many other women have been suffering like me-maybe a million women have become victims of polygamous marriage. Some of them became insane; others were murdered or committed suicide because of severe depression. There are many items in the newspaper about them [murder and suicide], and it is possible that they are caused by polygamous marriage... (Quoted in Nurmila, 2009, p. 99).

Certainly co-wives of a husband feel battered and subordinated as they go through different stages of somatization, depression, anxiety, hostility, psychoticism and psychiatric disorder. Muslim women who belong to this category tend to show a bit of resistance to their husband's polygynous marriage and believe that a man should not be allowed to have another marriage without any reasons. They believe that as long as the first wife can serve the husband, there is no need for another wife. However, they cannot resist too much because of the domination of patriarchy in the societies. There is a prevalence of domestic violence in these polygynous marriages where the male of the family inflict pain and agony on his wives and children. The patriarchal nature of these Muslim societies allows them to do so as the family law of the state privileges male over female as well. The subjective patriarchal interpretation of the Quran penetrated the state's family law of so many Muslim countries. On patriarchal nature of the state's law in Muslim countries, Al-Hibri (2000, p. 53-54) argues in her article "An Introduction to Muslim Women's Rights":

Unaware that Satanic logic provided the underpinnings of a patriarchal world, most Muslim jurists (like their societies) uncritically upheld central thesis of patriarchy, namely, that males were superior to females. This central patriarchal assumption distorted their understanding of Qur'anic text and led them to develop oppressive patriarchal jurisprudence. This patriarchal jurisprudence then became the basis of state laws that have oppressed women for centuries.

For Al-Hibri, the patriarchal interpretations of the Quran are subjective and unacceptable as they are not in synch with the concept of unity of God. These subjective and unacceptable male interpretations of the Quran have, unfortunately, become the family law of Muslim countries where male is put superior to female and where it favors a husband's rights and privileges. Regarding polygyny, the law in some Muslim countries allows it without any terms and conditions; in some other countries, it is a prerequisite to ask for permission from the Islamic court and some other Muslim countries allow polygyny if the first wife consent to the second marriage. 
Whatever the law is, the male is, oftentimes, privileged. This sentiment can be corroborated with Leila Ahmed's comment "[f]amily law is the cornerstone of the system of male privilege set up by establishment Islam" (1992, p. 242) which indicate the patriarchal nature of Muslim family laws in Muslim countries.

\section{Four Wives-One Man}

'Four Wives-One Man' is a documentary on a polygamous family produced and directed by Nahid Persson. It is an intimate illustration of a polygamous family in a rural village in Iran. This documentary follows the daily lives of four women who are married to a sheep farmer, Hedayat. The film shows how the situation of a polygynous marriage has turned the co-wives into both bitter rivals and co-conspirators against their abusive husband. The opening scene exhibits one of the twenty children of Hedayat drawing a big heart and accommodating four more hearts within the big one. He calls the big one "my dad's heart" and the four within are his dad's four wives'. Hedayat has just recently married Ziba as his fourth wife and she is his favorite. The other three wives complain while their astoundingly free-spoken mother-in-law comments on her son's lustful way of life: "All my son thinks about is pussy!" The other wives maintain that "he doesn't care about us. He is always with his latest wife, Ziba" but they still love him as they say "we are forced to love him because he is the father of our kids." However, they complain that Ziba, the new wife, receives more physical and emotional recognition from Hedayat; thus, there are no egalitarian sexual relationships.

Hedayat thinks he is a prosperous farmer. He proudly notes that his income and sheep allow him to make his family happy and provide for his twenty children, four wives and an aging mother. However, he is a poor man with little financial prospects to his credit, but still manages to marry four women and has twenty children to support. He cannot give enough financial support to each of his four wives and their children. Most of the time, the four wives are asking for maintenance for which they either get nothing or receive very little in response. It is not just financial problems in his family but there is also the emotional stress that his wives and children go through every day. The four wives suffer emotionally when they see Hedayat spends inadequate time with them and the children; and when he allots some time with his wives and their children, he usually ends up in blaming them and shouts at them that he does not have much money to support. They even cannot enjoy emotional intimacy or companionship with their husbands. Hedayat's first wife maintains that she was beaten up to consent to the second marriage. The other two wives were also unhappy with Hedayat's fourth marriage. They tried to talk him out of the fourth one but in vain. Beating up was the answer to the wives' request of not getting another co-wife.

This is of commonality in polygynous marriages. Women are often disconcerted by their position as a co-wife with hardly any authority. The wives are regarded like property by their husbands who then use, abuse and dispense with them at will. These wives possess no freedom of movement, speech and association. Their husband domesticates and regulates their body; therefore, these wives go through different kinds of psychological and physical violation. The wife's body in these marriages has turned into a readily accessible locus of masculine's domestic violence, exclusion and abuse. Taken for granted that polygynous marriages is accepted in Islam, Hedayt, by no means, is following the Sharia as being fair and just to the wives is recommended in polygynous marriages. After spending some time with Ziba, Hedayat starts talking about getting a new wife. Because Ziba is infertile and was a widow before marriage, this time Hedayat yearns for a virgin. He says it is good to marry a virgin as "they're the best. They don't know anything. You tell her it is day; she will say yes, it's a day. You tell her it is night and she'll say it's a night." He is, in fact, looking for a simple and gullible girl to never disobey. Ziba puts a lot of effort in preventing him to marry a fifth wife, but Hedayat says "I am still young and I can get a new wife. You are a barren woman. It is like if a well runs dry, you have to dig a new one. Besides, she can help you with the home's chores and you can rest a bit." Nothing that his mother and the other three wives say manages to persuade him otherwise. The four wives know that having another co-wife is a pity as it enhances the vicissitudes for every family member.

Eventually, he marries a young girl as his fifth wife. The closing scene shows Ziba waking up in the morning and going out to at the front door of her house. It is the very same day of the arrival of the new wife. Hedayat comes home on a motorbike with the brand new bride on the pillion. Ziba smiles forcefully and when they get in to go the room, she throws the keys for the new wife. Hedayat seems very happy as he is going to have a sexual intercourse with the new wife. The young wife looks sanguine about her marriage to Hedayat and she thinks it would be a rosy life and can overcome any problems by loving Hedayat unaware of the fact that she has just started a life replete with jealousy, physical beating, emotional stress and psychological problems. Hedayat, indeed, adopts polygyny for the selfish and phallocentric reasons of his excessive sexual lust. This story could be an obvious illustration of polygyny in Muslim societies. However, it should be noted that polygyny in Iran is of a rare phenomenon in urban areas and it is not socially accepted. Nahid Persson made the documentary to educate 
the silenced women and to increase the awareness to the problems caused by polygyny in Muslim communities.

\section{Education of the Less Known}

To educate the Muslim society, especially women on polygyny,a great deal of attention should be paid to the reinterpretation and retranslation of the Quran as some Muslim scholars believe that the Quran should be reinterpreted and retranslated. Ali Shariati and Al-Hibri are such scholars who opine that the Holy Quran has different interpretations in different eras. Generally speaking, the Textualist and Semi-textualist interpretations of the Quran are not appropriate as regards to polygyny. Muslim women need to know that verses in Quran should not be examined isolated from the whole spirit of the Quran and the whole contexts of their revelation. There are a very small number of people who argue that it is the context and norms of the Holy Quran which have to be considered to comprehend the real intention of the verses; this group is called Contextualist in Saaed's (2006) categorization. The traditional and patriarchal interpretations refer to only verse 4:3 for polygyny and they do not take into account all the concerned verses. Oftentimes, they quote one verse from Quran to prove their perspectives. Syed (2004, pp. 41-42) is of the idea that to understand God's intention on polygyny, the following verses of the Quran should be scrutinized:

"O mankind! Reverance your Guardian-Lord, who created you from a single person, created of like nature his mate ..." (4:1)

"To orphans restore their property (when they reach their age), nor substitute (your) worthless things for (their) good ones; and devour not their substance (by mixing it up) with your own. For this is indeed a great sin.

If you fear that you shall not be able to deal justly with the orphans, marry women of your choice, two, or three, or four; but if you fear that you shall not be able to deal justly (with them), then only one, or (a captive) that your right hands possess. That will be more suitable, to prevent you from doing injustice." (4:2-3)

"They ask your instruction concerning the women. Say: God does instruct you about them: and (remember) what has been rehearsed to you in the Book, concerning the orphans of women to whom you don't give the portions prescribed, and yet whom you desire to marry, as also concerning the children who are weak and oppressed; that you stand firm for justice to orphans. There is not a good deed which you do but God is well acquainted therewith." (4:127)

"You are never able to be fair and just as between women, even ifit is your ardent desire: but turn not away (from a woman) altogether, so as to leave her (as it were) hanging (in the air). If you come to friendly understanding, and practice self-restraint, God is oft forgiving, Most Merciful." (4:129)

These verses are equally significant to realize the Quran's point of view to the controversial issue of polygyny. Different Islamic scholars and theologians reexamined these verses in the light of their revelation. They believe that verses 4:1, 4:2 and 4:3 must be read together. Verse 4:1 emphasizes the egalitarianism of both sexes when it refers to creation of male and female from the same source. Verse 4:2 encourages Muslim to offer their property to orphans and not to replace their good property with worthless ones of the guardian of the orphans. The next verse asks Muslims to be just to orphans and seemingly allows polygyny only if there is an understanding of justice. The permission to marry "that which your right hand possesses" (4:3) hints to slave women which is not relevant today as the time of slavery has passed long. The term 'women' in 4:3 means the mothers of the orphans. Here, the stress is on doing justice to the orphans rather than marrying one woman (Syed, 2004). Even considering this single verse, the Quran does not allow polygyny according to whim of a man. It stresses on justice between women which literally never happens. One might be just in terms of giving equal amount of maintenance and equal facilities to all the wives but certainly, one cannot be just in loving the wives equally. Equal love is humanly impossible as a man always tends to love one of his wives more than the other wife or wives (Ali, 2002). Thus, this single verse itself repudiates polygyny.

Many interpreters and commentators of the Quran consent upon the fact that these verses were revealed soon after the Battle of Uhud to encourage Muslim men to marry the war widows. Muhammad Ali (1951) confirms this sentiment as he argues that the Quran permitted Muslim men to have more than one wife because many Muslim men were killed in the battle and left behind a great number of women and children. Another Islamic scholar, Zamakhshari (1977) opines that God has permitted polygyny just in case of orphan girls and their guardians who were left behind after the battle; God never allowed polygyny as a general practice for Muslim men. Verse 4: 129 cautions Muslim men against hazards of multiplicity of wives and makes it complicate for a Muslim man to fulfill the terms of polygyny as it mentions one cannot be just to his wives even if he wishes so. Consequently, once the equal treatment of the wives cannot be fulfilled, polygyny is as good as banned. Therefore, the two traditional interpretations are refuted as they are interpreted in favor of male. The 
Contextualist's interpretations make the religion friendlier towards women. Contextualist scholars such as Laleh Bakhtiar translated and reinterpreted the whole Quran from an egalitarian point of view. Her translation shows equality between men and women. The following verse 4:32 illustrates this fact:

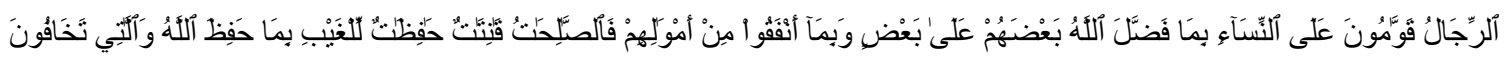

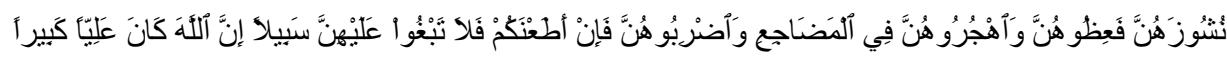

For over 1400 years, this verse has been interpreted as "rebellious women should first be admonished, then left alone in bed, and ultimately beaten" (4:34). This interpretation is challenged by Bakhtiar who contends that the Quran does not tolerate domestic violence. She translates this verse as "[a]nd those females whose resistance you fear, then admonish them, and abandon them in their sleeping places and go away from them." She is of the idea that when the word 'idrab' in Arabic has 25 different meanings in which one of them is 'to go away,' why it should be translated as 'beating' when Prophet Muhammad (pbuh) never did so in his life. Furthermore, she argues that Islam is the religion of peace and equality and never encourages domestic violence. Other interpreters argue that Bakhtiar is wrong as the old interpretation does not suggest physical beating. They argue the word 'idrab' suggests beating gently with a toothbrush. However, the concept of beating puts women in an inferior position to that of men which is not true in Islam where men and women are equal. Contextualist interpretation of the Quran can educate the silenced women that polygyny is not a holy practice and should not be appropriated easily. Ironically the same visual culture that promotes polygyny and gives men a privileged status over women can also be a successful strategy to make women aware of the less known. However, since the dominant visual culture is monitored by the government, social media could be an alternative venue for propagating the less known.

\section{Conclusion}

The idea of polygyny sounds horrifying as it breaks the commitment to be faithful. It cannot be the answer to the social problems. However, Muslims worldwide think otherwise and practice it. In a country like Malaysia, the mass media such as TV, newspapers and magazines is recruited to normalize polygyny. Visual culture is a means to promote images of the seemingly happy polygamous families in Malaysia. Some Muslim men practice it at their whim and marry four wives to gratify their sexual needs which sound like harem in a house; hence, it is like domesticating the harem. The conservative framers of the Islamic Sharia encourage polygyny and Muslim women think it is God's law and should not disobey otherwise it would be a disavowal of religion. Wives in polygynous marriages go through different stages of financial, emotional, physical and psychological problems but remain silent as they have been told polygyny is permitted and encouraged in the Quran. Unfortunately, polygyny is a legally accepted practice that eventually supports machoism at the cost of existing wives' self-respect and happiness. These women are unaware of the reality that by resisting polygyny, they do not question and disobey the Quran, rather they question the interpretation; the Holy Quran is sacred but not the interpretation. It is equally unlawful for men to have more than one wife, if a woman is not allowed to marry more than one husband. The modern or contextualist interpretation of the Quran can educate Muslim women that polygyny is not encouraged in Islam.

\section{References}

Ahmed, L. (1992). Women and Gender in Islam. Michigan: Yale University Press.

Al-Hibri, A. Y. (2000). An Introduction to Muslim Women's Rights in Windows of Faith: Muslim Women Scholar-Activists in North America. In G. Webb (Ed., pp. 51-71). New York: Syracuse University Press.

Ali, A. (2002). Polygamy in Islam-Concept and Practice. Retrieved from http://www.pucl.org/Topics/Gender/2002/polygamy-islam.htm

Bretschneider, P. (1995). Polygyny: A Cross-Cultural Study. Uppsala: [Uppsala University]; Stockholm: Almqvist \& Wiksell.

Jones, G. W. (1994). Marriage and Divorce in Islamic South East Asia. Kuala Lumpur: Oxford University Press.

Lane, G. (2010). Polygamy Hot Button Issue in Malaysia. Retrieved from http://blogs.cbn.com/globallane/archive/2010/08/05/polygamy-hot-button-issue-in-malaysia.aspx

Mirzoeff, N. (1999). An Introduction to Visual Culture. London: Routledge.

Mitchell, W. J. T. (1994). Picture theory. Chicago, University of Chicago Press.

Mokhtar, M. (2010). Malaysia's Polygamous Marriages Carry an Undercurrent of Inequality. Jakarta Golbe. 
Retrieved from http://www.thejakartaglobe.com/archive/malaysias-polygamous-marriages-carry-anundercurrent-of-inequality/

Naik, Z. (2011). Why Muslims have four wives. Retrieved from http://www.youtube.com/watch?v=8Sdzfwen-yo

Nurmila, N. (2009). Women, Islam and Everyday Life: Renegotiating polygamy in Indonesia. Routledge.

Persson, N. (2007). Four wives- One Man. Retrieved from http://www.youtube.com/watch?v=IMfLzPzY2-s

Saeed, A. (2006). Interpreting the Qur'an: Towards a Contemporary Approach. New York: Routledge.

Syed, M. A. (2004). The Position of Women in Islam. State University of New York Press, Albany.

Zamakshari. (1977). Al-Kashaf. Beirut: Dar al-Ma’arif.

\section{Copyrights}

Copyright for this article is retained by the author(s), with first publication rights granted to the journal.

This is an open-access article distributed under the terms and conditions of the Creative Commons Attribution license (http://creativecommons.org/licenses/by/3.0/). 